Zoltán B. Nagy, Ph. D., Full Professor

University of Miskolc

Faculty of Law

jogdrnz@uni-miskolc.hu

Szilvia O. Somsák, Undergraduate Student

University of Miskolc

Faculty of Law

somsakszilvi0201@gmail.com

\title{
THE MICRO-AND MACRO LEVEL INSTRUMENTS OF FINANCIAL CONSUMER PROTECTION IN HUNGARIAN LAW
}

\begin{abstract}
The study deals with the legal questions of Hungarian consumer protection. The purpose of the paper is to reflect on nowadays issues of financial consumer protection and to demonstrate how does it affect everyday life. A malfunctioning monetary intercessory scheme is likely to give a rise to major imbalance in the structure of economy; therefore, consumers lose their persuasion in the reliability of financial institutions. Concerning the definition of consumer, the authors call out the contentious fields of the whole area of law while sketching some solutions of the Hungarian regulation. It is inevitable to be aware that without the services of financial institutions, the economic development is unimaginable. That is the reason why financial consumers have to face with injustices in most cases, concerning the monetary sector. The study puts injustice great emphasis on the consumer protectionist role and on the tools of the supervision, underlining the newly regulated macroprudential instruments. Based on experience, there is a need for softening the regulation of financial consumer protection, as long as it is an important, not just an individual-related question. There are different solutions for defending the rights of consumers, including the tool system of the financial supervision, the alternative dispute settlement conducted by the Financial Arbitration Board and the office of the financial ombudsman.
\end{abstract}

Key words: consumer, financial consumer protection, alternative dispute resolution, supervision, macroprudential instruments 


\section{INTRODUCTION}

The questions of financial consumer protection got into the focus of economic and legal regulation in connection with the economic crisis. Some problems arose around the way and extent of consumer protection including the question, how diversified the regulation should be? The consumer protection in the field of finances faces questions which do not arise in other consumer markets, and the social importance of financial consumer protection comes to the fore next to the individual consumer harms. During the analysis, the study takes into account the results of European Union's regulation, but primarily, demonstrates the results of the Hungarian regulation, concentrating on the emerged problems.

In the study, we are seeking an answer to the following questions: in which cases can be the consumer defended, and in favor of rights' protection, what kind of financial-legal instruments can the state apply? We are examining what can be the instruments of consumer protection.

Consumer protection is an interdisciplinary legal field which overlaps numerous other branches of law. Among others, we can find provisions in civil law, criminal-and infringement law, administrative law and several other sectoral acquis, such as financial, media service and utility law, and its institutional frames are defined by the consumer protection act. Compared to this, special regulation prevails in financial consumer protection.

The connection between consumer protection and civil law must be highlighted, as long as the general principles defining the relation of the consumer and the service provider are given by the civil law. Such principles are for example the cooperation and the bona-fide procedure. The norms of special contractual law belong here, which refer to certain contract types, such as sales contract and insurance contract. We can also find consumer-protectionist type rules among the general regulation referring to contracts. We can rate here the rules concerning unfair common contractual terms - which be examined in detail later on - and the regulation of avouchment, warranty, compensation and invalidity.

There is a need to emphasize the relation of administrative law and consumer protection, as the regulation of law in economy are controlled by the organs of state administration, through the minister responsible for consumer protection, the departmental ministries and other vocational authorities such as the Hungarian Competition Authority. ${ }^{1}$

Finally, we should put a stress on the consumer protection from the aspect of financial law, which seems to be supported by the public law-like regulation of the Hungarian Central Bank (MNB), and within its frames, the state controls the

\footnotetext{
${ }^{1}$ István Czajlik, Anna Horváth, Judit Sz.Pap, Bank Menedzsment (Bank Management), Nemzeti Közszolgálati és Tankönyv Kiadó, Budapest 2013, 438
} 
institutions carrying out financial services. Thus, financial law gives the framework of the state's money- and property management. In Hungary, under the field of financial law, we mean the public law rules of budget law, tax law and banking law. The MNB proceeds as a consumer protectionist authority in connection with financial topics, in consumer protectionist law violations of banks. Therefore, consumer protection law consists of public law rules and private law rules. The public law part stands for financial consumer protection law. Concerning public funds, we always find the authority on the one side, which means practicing the power of the state, thereof, the legal relations between the institutions dealing with financial services and consumers belong to financial law. However, in our home, financial consumer protection's structure is different from the functions of authorities responsible for general consumer protection. Namely, the consumer protection act states that its force does not cover the supervision of financial intercessory scheme of the MNB, in which it controls institutions and people dealing with financial services. ${ }^{2}$

\section{PROBLEMS CONCERNING VIOLATION OF FINANCIAL CONSUMERS' RIGHTS}

As a consequence of the economic crisis, an intense attention was directed towards the protection of consumers, especially financial consumers. From the above phrased thoughts, it is undoubtable that protection of the consumer is a significant public interest. It became obvious that finances are essential and crucial parts of our everydays, and this was not different in the previous centuries either. As a result of modern social development - next to the technical innovation - financial markets and financial constructions started to prosper fast, which are not totally clear even for the experts, thus, for the common people, they are downright impenetrable. On the track of change of the regime in 1990, the model of consumer society emerged in Hungary. The view of Paul Ekins - British professor - concerning sustainable economic progress is that consumer society is a society, where the primary cultural intention is the holding and usage of increasing number of goods and services, which is the most ensured way of getting to personal happiness, social status and national success. However, the desire for material wealth and services is more and more insatiable, exactly for the reason that it does not lead to real happiness. Banks were advertising citizen loans with advantageous conditions, though, the clients were informed one-sidedly. The benefits of loan constructions were emphasized out, while the negative side was not pointed out. The rise of the interest rate and installment, the increased costs of banking administration and

\footnotetext{
${ }^{2}$ Act CLV/1997 on Consumer Protection — CPA, Magyar Közlöny, No 102/2015
} 
the enhancement of the bank administrator's payments charged on clients aggravated the problems more. It is important to know that without sources of loan, the economic development is unimaginable. At the same time, the need for loans is a burden for the legislators, as they must create less strict regulation, considering that rigid regulation makes the expansion of market activity more difficult. On the other hand, the facilitation of the regulation can be detrimental not just for the consumers and society, but for the financial institutions as well. The financial institutions can employ unfair conditions that cause damage for consumers, but parallel to their own momentary advantageous situation, they can risk loss-making functioning in the long term, and all these will influence the whole society. A bad-functioning financial intercessory scheme can cause significant imbalance in the economy's structure, consumers lose their faith in the trustworthiness of financial institutions. An upcoming bankruptcy wave means great relapse in economic development. ${ }^{3}$ By the 21 st century, financial sphere has become an outstanding factor, as long as the result of the economic crisis has brought along so remarkable changes, which made the question of financial consumer protection a key-factor. Thanks to the financial crisis, already existing problems emerged, for which the regulation could not wait any longer. It is visible that a completely liberal regulation will not improve the stability of financial markets, a crisis requires state intervention. The stabilization of financial situation leads to the violation of social interests based on the principle of ,privatizing the profit and nationalizing the loss”, because the money of taxpayers must be spent on consolidation. ${ }^{4}$

Putting aside finances (but not separated from it completely), we can talk about consumer in general, which includes financial consumer as a narrower category. It can be ascertained that the concept of consumer has more approaches, which show a lot of similarities in the consumer protection directives, but the situation environments in which they are employed are different, so we cannot talk about an absolutely unified European consumer concept. ${ }^{5}$ According to one approach, the consumer is a natural person, who acts on affairs under the force of the directive, which is out of his profession, business activity or employment. ${ }^{6}$ Another directive has a completely different approach, which is not restricted only to natural persons, but comprise of legal persons too.

${ }^{3}$ Zoltán Nagy, "Problémafelvetések a pénzügyi fogyasztóvédelem területén" ("Problems concerning financial consumer protection"), Miskolci Jogi Szemle, 2.XII.2017, 391-393

${ }^{4}$ A pénzügyi fogyasztóvédelem aktuális kérdései (Actual questions of financial consumer protection), 2014. 207-209. http://www.vmtt.org.rs/mtn2013/207_223_Nagy_A.pdf, 28, September, 2018

${ }^{5}$ Zsolt Hajnal et al., Magyar fogyasztóvédelmi magánjog - Európai kitekintéssel (Hungarian consumer protection private law-with a European outlook), Debrecen 2010, 43

${ }^{6}$ Directive 2008/48/EC of the European Parliament and of the Council of 23 April 2008 on credit agreements for consumers and repealing Council Directive 87/102/EEC, Official Journal of the European Union, 22 May 2008 
In Hungarian law, under the concept of consumer we mean self-dependent, natural person, acting on aims outside his employment and economic activity. Thus, sole traders, individual companies, economic corporations, legal persons, institutions without legal personality, condominiums are not considered as consumers (and cannot initiate the procedure of the Financial Arbitration Board (PBT)). ${ }^{8}$ Another legal formulation says that the consumer is a natural person who acts on affairs outside his separate employment and economic activity, who buys, orders, receives, uses, resorts to products or is the addressed of product-related commercial communication and offer. ${ }^{9}$ Consumer relationship is a legally regulated social relationship existing within the framework of civil law, whose specialty is that in principle, equal persons stands at the two sides of the relationship, in a way that the consumer pursues to fill his needs, while the other signatory accomplishes economic-financial goals through the business. ${ }^{10}$ Hence, under the concept of financial consumer we mean a natural person, who resorts to the services of a financial institution, besides the intention of his or her own profession and economic activity.11

We should not forget about making clear the theoretical question that defines, which cases of the consumer attitudes merit protection by the law. We can differentiate between two consumer patterns, the first is the model of rational consumer (this prevails in the legal practice of the Court of Justice of the European Union), who is able to make reasonable decisions based on the information at disposal, and the second is who cannot decide logically, is easy to mislead, therefore he must be protected exceptionally. At the same time, legal practice acknowledges that rational consumer is still in an adverse situation compared to the services and financial institutions, even if he proceeds circumspectly, because of his level of information and restricted negotiation possibilities. He either accepts the conditions defined beforehand or not, but cannot modify them. Because of the low degree of financial culture and higher efficiency of financial service providers, the ability to enforce interests meets with difficulties in Hungary. ${ }^{12}$ After all, we should see that the aim to protect consumers is in contrast with the principles of contractual freedom and will-autonomy.

${ }^{7}$ Act V/2013 promulgating the Civil Code, Magyar Közlöny, 31/2013

${ }^{8} \mathrm{Ki}$ a fogyasztó? (Who is the consumer?) https://www.mnb.hu/bekeltetes/fogyasztoi-jogvita-nem-elszamolasi-ugyekben/penzugyi-fogyasztoi-jogvitam-van-kerelmet-szeretnek-benyujtani/ ki-a-fogyaszto, 26 September 2018

${ }^{9}$ CPA, Magyar Közlöny, No 102/2015

${ }^{10} \mathrm{Ki}$ a fogyasztó? (Who is the consumer?), http://drvargazsanett.hu/ki-a-fogyaszto/, 26 September 2018

${ }^{11}$ Act CCXXXVII/2013 on Credit Institutions and Financial Expediencies, Magyar Közlöny, $217 / 2013$

${ }^{12}$ Z. Nagy, 393-394 


\section{SOLUTIONS FOR THE PROTECTION OF FINANCIAL CONSUMERS}

\subsection{The financial supervision and its tool system}

Among others, the aim of the supervision is the efficient and transparent functioning of the intercessory system along with its tranquillness, the exposure and reduction of the risks, the boost of public confidence and maintenance of the predominance of the present regulation, so as the stability of the financial system irrespective of the institutional form. A stable financial system is capable of resisting to the economic concussions by recognizing the risks on time and by treating them in a proper way. The role of the supervision is to make everyone keep the norms constituting the basis of the legitimacy of financial regulation, and the measures based on them. Within this, it must ensure the protection of actors in the market on the one hand and the protection of consumers on the other hand, and the enforcement of fair competition as a general aim. The supervision must fence off the negative effects of financial crisis, maintain the trust casted in the financial system, stand up against the abuses and last but not least, combat with financial crimes which constitute a large amount of today's crimes..$^{13}$ Beyond that, the supervision must strive to steady the market discipline and to solve the problems arising around the system of banks. These requirements can only be fulfilled by developing the information flow, the transparency, the cooperation between authorities and by unifying the financial reporting system. The essence of the prudential regulation is to minimalize the risks shouldered by the banks and to guarantee the healthy and secure operation of the financial institutions and the banking system.

Banks are similar to „hazardous operations” in nature, by playing an important role in the economy, implementing financial transactions. Meanwhile, the clients are generally not in the possession of the whole information, thus, there is a need for making available the necessary orientation by the supervisory body concerning financial products and the particular financial institutions. Financial products apply for far more foresight than the products of the other industrial sectors, consequently, the consumer protection requires an efficient control mechanism. As a result of the fast transformation of European financial markets, some doubts have arisen in connection with separate, sector-specific supervisions. ${ }^{14}$ On the whole, the proper operation of the financial intercessory system is such a social interest that unconditionally calls for the functioning of a protective system through state intervention.

${ }^{13}$ Zoltán Nagy, Anett Csiszár, A hazai pénzügyi felügyeleti szabályozás a változások tükrében (The regulation of domestic financial supervision in the light of transformation), Publicationes Universitatis Miskolcinensis, XXXIV/2016 157-172

${ }^{14}$ Z. Nagy, 397-400 
During the control of the whole financial intercessory system, the Financial Stability Council (PST) of the MNB exposes the risks threatening the system, which consist of extensional and temporal dimensions. System-risk is the chance of one or more shocks affecting the particular elements of the system will concern other elements as well via inner connections, and finally, the whole system will collapse. In a narrower sense, we can talk about system-risk when an exact event influences a tight sphere of economy and then, with the marching of time, it affects unfavorably one or numerous institutions and markets because of chain of events. In a broader sense, we regard it as system-risk when the exact event simultaneously effects several institutions and markets as a result of a heavy and extended shock. ${ }^{15}$ If it is necessary, the PST sticks the recommendations, statements and risk notifications, relevant to the whole financial intercessory system, to the European Systemic Risk Board's schedule. Moreover, in a situation which is threatening the stability of the whole financial intercessory system, the PST evaluates the system-risks and decides about measures in favor of decreasing or abolishing them. ${ }^{16}$ The macroprudential tools, like the means of preventing excessive growth of loans, the means of dealing with liquidity and financing risks, the instruments of restricting the exaggerated concentration and the tools of smothering the system-risk booster bad stimuli - as being part of macroprudential policy - are in service of prevention and management.

In its annually published second, called Macroprudential report, the PST demonstrates the macroprudential instruments aiming at the prevention and the handling of the exposed system-risks and their effect mechanism, in a way that the implied arrangements become comprehensible to the general public as well. ${ }^{17}$

The possible instruments of decreasing the system-risks can be generally divided into temporal dimension and intersection dimension. The temporal dimension includes the determining of the counter-cyclic capital puffer, bigger provisions (dependent on bankruptcy), higher risk burdens in case of certain loans and credit-growth maximum. Inside the intersection dimension, we can find the change of capital demands in case of large-scale out placed loans, the restriction of interbank loans, the maximums of credit-deposit ratios, and the capital-transfer limits. ${ }^{18}$

For those consumers who wish to borrow money from the bank, the admissible amount of loan is maximized in the ratio of the credit protection, while the

\footnotetext{
${ }^{15}$ Rendszerkockázatok modellezése (Modeling of system risks). Budapest, http://web.cs.elte. hu/blobs/diplomamunkak/msc_actfinmat/2017/kunne_szabo_eszter.pdf, 29 October 2018

16 Pénzügyi Stabilitási Tanács (Financial Stability Council) https://www.mnb.hu/penzugyistabilitas/penzugyi-stabilitasi-tanacs, 29 October 2018

${ }^{17}$ Makroprudenciális jelentés (Macroprudential report), https://www.mnb.hu/kiadvanyok/ jelentesek/makroprudencialis-jelentes, 29 October 2018

18 Anikó Szombati, A mikroprudenciális felügyeleti hatáskör Magyarországon, Bankmenedzsment ( The microprudential supervisory authority in Hungary, Bankmanagement) Budapest 2013, 138
} 
payable installments are maximized in the ratio of legal income of the household. It means that the consumer can borrow as much money as the pledged item is sufficient for the restitution of the debt and the continuous repayment of the debt is adjusted to the consumer's salary. With regard to the general 15-20 years duration of the real estate loans, it is important to ensure that the possible changes of interest rates in the long term do not result in payment hardships or in extreme cases, payment incapability on the side of households. In case of changing of short-term fixed interest rates concerning real estate loans, it can happen that the unfavorable interest rate change comes along with the significant increase of households' installment burdens. Accordingly, based on the new income-proportionate installment regulation, to the real estate loan applications with duration of longer than 5 years and received after October 1, 2018 - dependent on the loan's interest-period - being lower than the actual, income-proportionate installment rate limits must be used. Therefore, the modified prescriptions ensure that the households possess appropriate income backups in case of an unfavorable interest rate change. The regulation has double effect-mechanism. On the one hand, the adequately calibrated limits are able to withhold the excessive loan emission, thus, they reduce the possibility and rate of recruiting cyclic hazards. Likewise, these can be efficient accessories to the anti-cyclic capital puffer, as the capital puffer influences the supply, while the „debt brake" regulation affects the demand side in the loan market. The anti-cyclic capital puffer is a flexible capital requirement fluctuating in time, which means that they create further capital puffer above the traditionally expected capital demand in the period of excessive extension of credit stock, which can be used in the recessionary period. Consequently, the created additional capital serves the cover of bank losses and also alleviates the amplitudes.

Beyond that, the risk of non-completion is directly decreased because the evolvement of exaggerated indebtedness is prevented. Because of the unique loan-contract effect of the instrument, it serves the regulatory intention reliably. We can mention here the determination of the minimum level concerning the risk burden of the out placed loans covered by real estate, and the rate of average non-compliance. The capital requirements can be reduced by the moderation of out placed real estate loans and can be counterweighed with higher interest rate additional charge. ${ }^{19}$

\subsection{Financial Arbitration Board (PBT)}

The MNB is committed to financial consumer protection and to market supervision in connection with screening out unauthorized, non-licensed or

\footnotetext{
${ }^{19}$ A rendszerkockázatot erősítő rossz ösztönzők tompítását szolgáló eszközök ( Tools aiming at smoothing the bad stimuli which intensify system risks), https://www.mnb.hu/penzugyi-stabilitas/makroprudencialis-politika/a-makroprudencialis-eszkoztar/a-rendszerkockazatot-erosito-roszsz-osztonzok-tompitasat-szolgalo-eszkozok, 29 October 2018
} 
non-announced financial service providers. The MNB protects the rights of consumers who resort to financial services, it orientates the service providers in the direction of a responsible, decent behavior. It identifies the harmful phenomenon for consumers as soon as possible and concentrates on the exposure of the reasons and on abolition, hereby preventing their repeated emergence. During its consumer protectionist monitoring, it focuses on the system irregularities which influence a large-scale of consumers.

The PBT, operating next to the MNB, is a professionally independent, alternative forum of dispute settlement. The PBT offers faster and cheaper solution than the arbitral proceedings concerning legal disputes requiring civil procedure between consumers and contracted financial service providers. The primary task of the Board is to attempt the formation of an agreement to arrange the legal dispute between the parties. So if there is a dispute in an exact case between the client and the financial service provider, the consumer does not have to reach to the court right away to solve the dispute. Experience shows that consumers often feel themselves defenseless against a financial institution, because they are not completely aware of the relating regulation, so they do not dare to start the proceeding, as a consequence of the more advantageous position of the financial service provider. This is the reason behind the establishment of the PBT, which can offer a solution in a non-judicial way. ${ }^{20}$

If the consumer is not satisfied with the decision of the PBT, he can still turn to the court for judging his claim, hence, the alternative dispute settlement do not deprive the possibility of the judicial way. As long as the decision or recommendation of the Board is harmful for the consumer, he can ask for the annulment of the decision from the court. However, the financial service provider can only ask for the annulment of the decision or recommendation if it contains obligation. If the financial service provider does not accomplish the approved arrangement or the decision containing obligation by the deadline, the consumer can ask the court to supply the Board's decision with an executive clause. ${ }^{21}$

\subsection{Financial ombudsman}

In Hungary, the bureau of the financial ombudsman had been existing only for a short period of time. The establishment of this office was decided by the Parliament on 19th November in 2012 for the reason that foreign exchange debtors not suffer again such serious losses, as it happened before. Its primary goals were

\footnotetext{
${ }^{20}$ Alapok (Basics), http://akadalymentespenzugy.hu/jogorvoslat/a-penzugyi- bekelteto-testuletahol-a-fogyaszto-es-a-penzugyi-szolgaltato-nagy-esellyel-megegyezik/alapok/, 30 October 2018

${ }^{21}$ Amit a Pénzügyi Békéltető Testületről tudni kell (What should be known about the Financial Arbitration Board) https://www.mnb.hu/archivum/Felugyelet/root/fooldal/pbt/bal_menu/a_ pbt_mukodese/altalanos_informaciok, 30 October 2018
} 
defined as counseling in consumers' particular cases and proceeding in favor of them. For the latter, it received authority ex officio, regarding certain matters. Besides these, it had the right to propose new acts and amendments if it was necessary.

Furthermore, spreading financial knowledge and financial culture were important aims as well. ${ }^{22}$

All of that would serve the elimination of inequality between consumers and financial institutions. Nevertheless, these hopes did not come true, as the financial ombudsman asked for his exoneration in 2013 from the minister responsible for national economy, who did not only accept his resignation, but ended the office of the financial ombudsman.

\section{CONCLUSION}

Based on this study, it can be ascertained that the regulation of the financial consumer protection is going through a transformation and on the fields of particular legal instruments there are still debated viewpoints conflicting each other. Among others, the statement that the concept of the consumer can be allocated from different directions is true, because the study demonstrates well that different legal sources contain varied definitions of the financial consumer. The reason of this, is that everyday life produces diverse situations, therefore in the exact situations other and other main elements were grabbed and included in the concepts. The other problematic issue with the financial consumer protection is being a complex field of law, as we can observe that the regulation and prescriptions concerning consumer protection can be found in various legal sources, like in civil law, financial law and EU law. Anyhow, the protection of the financial consumer is a significant social interest, that is why it is important to determine the situations in which the consumer can be defended and with which kind of instruments can the state provide for that defense.

In conclusion, we can assure that financial consumer protection is such an essential area of law which is difficult to confine, although, the need for that is indisputable. Participating in the world of economy and law as financial consumers is an indispensable part of all our lives. The consumer rights and obligations play an important part in everyday life, even if we are not aware of that. In our opinion, having a clear knowledge about the basic financial concepts and financial products is crucial for everyone, as long as consumer society is built upon these. Acquiring the adequate knowledge is very circumstantial and one cannot manage completely to do it so. As a consequence, many advisory and dispute settlement

${ }^{22}$ Egyedi ügyekben is eljárhat a pénzügyi ombudsman ( The financial ombudsman can proceed in particular cases as well) https://mno.hu/belfold/egyedi-ugyekben-is-eljarhat-a-penzugyi-ombudsman-1119248, 30 October 2018 
bodies have been established, which can complement and redress the defects that could not be handled by the financial supervision.

Our strong conviction is that a great emphasis should be put on the cognition of financial constructions, as far as economy is a so compound mechanism where we need a proper amount of background information to be able to enforce our rights individually.

Nevertheless, the MNB should provide for a level of financial supervision, next to which the cases happening in the last few decades, causing serious losses for consumers, could not happen again in the future. Besides that, the central bank could apply the previously mentioned counter-cyclic capital puffer, bigger provisions, higher risk burdens in case of certain loans, credit-growth maximum, change of capital demands in case of large-scale out placed loans, restriction of interbank loans, maximums of credit-deposit ratios and capital-transfer limits, which can play a part in the defense of financial consumers.

It is clear that the frames of responsibility are not defined as required, thus, the liability is not compliant, and the harmed ones cannot enforce their demands and fight against the abuses by efficient guarantee. The institution of the PBT and a financial ombudsman would be a good base for arranging consumer disputes, but it would not be a fully reliable solution for handling the problems. As far as we are concerned, there is a need for more regular, accurate and broader monitoring within the framework of the supervision, which is capable of exposing and confining the infringements in time. Moreover, it is necessary to work out a stricter sanction system for the already happened violation of rights, which has the function of reparation and repression, thereby it has a preventive character as well. Beyond that, we consider it inevitable to compose rigid rules of organization and operation, which would be resulted in larger limitation on institutions, letting smaller margin to the abuse of rights. In our beliefs, emphasizing more the financial consumer protection and constituting a system of guarantees are essential for the consumers to be capable of placing unconditional confidence in the financial system. All in all, there is a strong need for establishing and restructuring a quite diverse regulation in connection with sort of situations, where the financial consumer resorts to various financial services of monetary institutions.

\section{REFERENCES}

Anikó Szombati, A mikroprudenciális felügyeleti hatáskör Magyarországon, Bankmenedzsment (The microprudential supervisory authority in Hungary, Bankmanagement) Budapest 2013

István Czajlik, Anna Horváth, Judit Sz.Pap, Bank Menedzsment (Bank Management), Nemzeti Közszolgálati és Tankönyv Kiadó, Budapest 2013 
Zoltán Nagy, "Problémafelvetések a pénzügyi fogyasztóvédelem területén" ("Problems concerning financial consumer protection"), Miskolci Jogi Szemle, 2.XII. 2017

Zoltán Nagy, Anett Csiszár, A hazai pénzügyi felügyeleti szabályozás a változások tükrében (The regulation of domestic financial supervision in the light of transformation), Publicationes Universitatis Miskolcinensis, XXXIV/2016

Zsolt Hajnal et al., Magyar fogyasztóvédelmi magánjog - Európai kitekintéssel (Hungarian consumer protection private law-with a European outlook), Debrecen 2010

Act V/2013 promulgating the Civil Code, Magyar Közlöny, 31/2013

Act CCXXXVII/2013 on Credit Institutions and Financial Expediencies, Magyar Közlöny, 217/2013

Act CLV/1997 on Consumer Protection - CPA , Magyar Közlöny, No 102/2015

Directive 2008/48/EC of the European Parliament and of the Council of 23 April 2008 on credit agreements for consumers and repealing Council Directive 87/102/ EEC, Official Journal of the European Union, 22 May 2008

A rendszerkockázatot erősítő rossz ösztönzők tompítását szolgáló eszközök (Tools aiming at smoothing the bad stimuli which intensify system risks), https://www. mnb.hu/penzugyi-stabilitas/makroprudencialis-politika/a-makroprudencialiseszkoztar/a-rendszerkockazatot-erosito-rossz-osztonzok-tompitasat-szolgalo-eszkozok

A pénzügyi fogyasztóvédelem aktuális kérdései (Actual questions of financial consumer protection), 2014. 207-209. http://www.vmtt.org.rs/mtn2013/207_223_ Nagy_A.pdf

Alapok (Basics), http://akadalymentespenzugy.hu/jogorvoslat/a-penzugyi-bekelteto-testuletahol-a-fogyaszto-es-a-penzugyi-szolgaltato-nagy-esellyel-megegyezik/alapok/

Amit a Pénzügyi Békéltető Testületről tudni kell (What should be known about the Financial Arbitration Board) https://www.mnb.hu/archivum/Felugyelet/root/ fooldal/pbt/bal menu/a pbt mukodeselaltalanos informaciok

A pénzügyi fogyasztóvédelem aktuális kérdései (Actual questions of financial consumer protection), 2014. 207-209. http://www.vmtt.org.rs/mtn2013/207_223_ Nagy_A.pdf

Egyedi ügyekben is eljárhat a pénzügyi ombudsman ( The financial ombudsman can proceed in particular cases as well) https://mno.hu/belfold/egyedi-ugyekben-iseljarhat-a-penzugyi-ombudsman-1119248

$\mathrm{Ki}$ a fogyasztó? (Who is the consumer?), http://drvargazsanett.hu/ki-a-fogyaszto/

$\mathrm{Ki}$ a fogyasztó? (Who is the consumer?) https://www.mnb.hu/bekeltetes/fogyasztoijogvita-nem- elszamolasi-ugyekben/penzugyi-fogyasztoi-jogvitam-van-kerelmetszeretnek-benyujtani/ki-a-fogyaszto

Makroprudenciális jelentés (Macroprudential report), https://www.mnb.hu/kiadvanyok/jelentesek/makroprudencialis-jelentes

Pénzügyi Stabilitási Tanács (Financial Stability Council) https://www.mnb.hu/penzugyi-stabilitas/penzugyi-stabilitasi-tanacs

Rendszerkockázatok modellezése (Modeling of system risks). Budapest,http://web. cs.elte.hu/blobs/diplomamunkak/msc_actfinmat/2017/kunne_szabo_eszter.pdf 
Zoltan B. Nad, redovni profesor

Univerzitet u Miškolcu

Pravni fakultet

jogdrnz@uni-miskolc.hu

Silvija O. Šomšak, student osnovnih studija

Univerzitet u Miškolcu

Pravni fakultet

somsakszilvi0201@gmail.com

\section{Instrumenti zaštite potrošača u finansijskim uslugama na makro i mikro planu u mađarskom pravu}

Sažetak: U radu se razmatraju pravna pitanja zaštite potrošača u Mađarskoj. Njegova svrha je da ukaže na aktuelne probleme pravne zaštite potrošača, kao $i$ na njihov uticaj na svakodnevni život. Greške u sistemu finansijskog posredovanja stvaraju rizik značajnije neravnoteže u strukturi ekonomskog sistema, zbog čega potrošači finansijske institucije više ne smatraju pouzdanim. U pogledu definicije pojma potrošača, autori ukazuju na različita shvatanja u doktrini i prikazuju neka rešenja usvojena u mađarskom pravu. Ekonomski razvoj je nezamisliv bez usluga finansijskih institucija. Ovo je razlog zbog kojeg potrošači ponekada moraju da trpe normativna rešenja u finansijskom sektoru koja smatraju nepravičnim. $U$ radu se posebna pažnja posvećuje funkciji regulatornog tela u zaštiti potrošača, merama kojima se ona ostvaruje, s posebnim osvrtom na nove makroprudencijalne instrumente. Iskustvo je pokazalo da postoji potreba za ublažavanjem regulative zaštite potrošača u finansijskim uslugama, kada za to postoji javni interes. Postoje različite mere za zaštitu prava potrošača, uključujući instrumente u sistemu finansijskog nadzora, mehanizam alternativnog rešavanja sporova, kao i aktivnost Finansijskog arbitražnog veća i finansijskog ombudsmana.

Ključne reči: potrošač, zaštita potrošača u finansijskim uslugama, alternativno rešavanje sporova, nadzor finansijskih institucija, makroprudencijalni instrumenti

Datum prijema rada: 17.09.2019. 